\title{
Management of Student with Special Needs in Inclusive Schools (Case Study in the State Junior High School 30 Surabaya and Alam Insan Mulia Junior High School Surabaya)
}

\author{
Rizka Rahma Nur Baiti ${ }^{1 a^{*}}$, Soedjarwo ${ }^{1, b}$, and Endang Purbaningrum ${ }^{1, c}$ \\ 1Department of Education Management, Post Graduated, State University of Surabaya, Surabaya, 60213, \\ Indonesia \\ arr.rizkarahma13@gmail.com; bsoedjarwo9@gmail.com; cendangpurbaningrum@unesa.ac.id \\ *Corresponding Author : rr.rizkarahma13@gmail.com | Phone Number: 085732795565
}

Received: 31 December 2020

Revised: 26 January 2021

Accepted: 23 February 2021

\begin{abstract}
This study was conducted to determine the management of students with special needs in schools at State Junior High School 30 Surabaya and Alam Insan Mulia Junior High School Surabaya by paying attention to student management which includes: (a) student planning, (b) student coaching, (c) student evaluation and (d) student mutation. Based on the problems or case studies that occur, at State Junior High School 30 Surabaya and Alam Insan Mulia Junior High School Surabaya, the management of students with special needs has many problems such as a lack of cooperation between educators and inadequate management processes for students with special needs. The method used is qualitative research, with a type of case study because it aims to obtain in-depth data and information so that the aim is to determine the implementation of management for students with special needs. The subjects of this study were the principal, deputy principal of student affairs, school teachers, coordinator of inclusion, teachers and homeroom teachers as well as most students with special needs from each school. Data collection techniques using observation, interviews, and documentation. The data analysis technique used in this study was an interactive analysis model consisting of three components, namely data condensation, data triangulation, data presentation and conclusion drawing.The results of research obtained at State Junior High School 30 Surabaya and Alam Insan Mulia Junior High School Surabaya show that the management of students carried out is mostly in accordance with the indicators in this study. The planning, coaching, evaluation and transfer processes are carried out in accordance with the procedures, vision and mission of the school and regulations of the education office. The inhibiting factors found were the lack of communication and cooperation between teachers, student coordinators with special needs and parents. This research is expected to be useful for researchers studying the field of inclusion and student management.
\end{abstract}

Keywords: Student Development; Management of Student; Children with Special Needs;

\section{Introduction}

All children, including children with special needs, have the same right to obtain educational services without any distinction from their ability background or physical condition. This is in accordance with Law Number 20 of 2003 concerning National Education article 5 paragraph 1 which states that every citizen has the same opportunity to obtain education, and in Article 11 paragraph 1 also states that the government and local governments are obliged to provide services and facilities as well as guarantee the implementation of quality education for every citizen without discrimination.

The importance of education for children with special needs, which is one way for them to develop their potential to be more advanced and independent, the government through Education Regulation Number 70 of 2009 gave birth to an inclusive education program as a form of effort to provide fair, responsive and friendly education services for everyone. students with the aim of (1) providing the widest possible opportunity to all students who have physical, emotional, mental, and social disabilities or have the potential for intelligence and/or special talents to obtain quality education according to their needs and abilities, (2) realizing the provision of education that respects diversity and is not discriminatory for all students.Kirk (2009), children with special needs need modification in school practice and special education services to develop their unique abilities. 
The existence of an inclusive education program not only sees the importance of education for children from all hierarchies, but also must be able to create a school atmosphere that respects multiculturalism (Smith, 2013: 43). Staub and Peck (1995 in Ilahi, 2013: 27), inclusive education is the full placement of children with mild, moderate, and severe disabilities in regular classes. This shows that the regular class is a relevant place of learning for children with special disabilities, regardless of the type of disability and regardless of the condition. Because the principle of inclusive education is to provide opportunities for each individual to develop their potential through appropriate educational services, because education itself is also a social function by determining the direction of development of immature students into participation in the life of the group where they are (Deway, 2012: 110). And that with the birth of inclusive education, it is hoped that all people as users of education services, especially children with special needs, can really get their rights, because inclusive education is the most effective way to eradicate discriminatory attitudes by creating friendly and responsive societies.

Therefore, an inclusive education system means that schools must be able to provide services to children regardless of their physical, intellectual, linguistic, social-emotional, or other conditions.Inclusive Education is developed based on the basic principle that education is for all people. Besides, the curriculum is compiled based on the children's needs including special needs'. Therefore, it needs flexibility, creativity, and sensitivity (Widyawati, et al, 2017). This means that inclusive schools provide educational services to children with special needs just like other normal children in general, so that they can adjust to their daily lives. The existence of inclusive schools is expected to provide great opportunities for children with special needs to receive education in regular schools designated as inclusive schools, so that children with special needs (later called ABK) can socialize well, mingle and be more acceptable in society.

Schools with inclusive education must be able to know and respond to the different needs of each student. Such as accommodating various kinds of learning styles, and ensuring the provision of quality education to all students. For that, of course, must go through good management. This is because in student management there is a demand to be able to provide an understanding between students (ABK) and other normal students who are expected to socialize together without any discriminatory action from normal students against students with special needs.

According to Knezevich (1961 in Kristiawan, et al., 2017) student management or pupil personnel administration is a service that focuses on managing, supervising and serving students in the classroom and outside the classroom such as introduction, registration, individual services, such as the development of overall abilities. , interests, needs until he matures in school. So, student management is an arrangement or arrangement of all activities related to students, namely from the entry of students to the departure of these students from a madrasa or school. Currently, there are around 25 State Junior High Schools (SMPN) in Surabaya that are listed as organizers of inclusive schools. To be able to run an effective inclusive school is not easy. Good management is needed, one of which is in matters relating to students with special needs, namely the management of inclusive school students. But in fact, there are still many schools that have not maximized the management of inclusive students.According to (Nurani, 2009:170) in inclusive education, it is not children who are required to adapt to the curriculum but it is the curriculum who must adapt to the needs of children for the development of all their human potential.

State Junior High School 30 Surabaya is one of the schools designated by the Education Office to organize inclusive education. This school began to organize inclusive education in the 2011-2012 school year in the even semester. Management of students who are good in management is intended to run effectively. According to Suwardi and Daryanto (2017: 110) student management activities include student planning, student development, student evaluation, and student mutations. In its management, the State Junior High School 30 Surabaya has several problems, such as there are still many teachers who do not understand the steps to determine the needs of students. In addition, in the learning process some students with special needs leave the classroom and make class conditions not conducive. Meanwhile, another problem is that there are still some students who have never attended lessons in the classroom.

In addition to State Junior High School 30 Surabaya, Alam Insan Mulia Junior High School Surabaya (SAIM), which is located not far from State Junior High School 30 Surabaya, also organizes inclusive schools at the Junior High School level. SAIM, which is a private nature-based school, also chooses to organize inclusive education even though in reality it is not easy to organize this inclusive education. Researchers believe that there are differences in the implementation of inclusive education between public and private schools because it can be seen that private schools have more space than public schools.Allen and Schwartz (2001) state the same thing that the teacher in either inclusive school or special school should be able to handle children with various abilities. According to Hargreaves, teacher's professionalism is exposed from the knowledge and ability in handling various students, and ability to support and develop each other. Moreover, teacher should be able to accept any criticism. This professionalism can generate positive emotion towards teacher (Troman \& Woods, 2001). 


\section{Materials and Methods}

The approach used in this research is qualitative research. In this research, the research design used is a case study. Case study research is a detailed study of one setting, or a single subject, or a document storage area, or a particular event (Bogdan \& Biklen, 2014). The reason the researchers chose the case study approach was because researchers wanted to obtain in-depth and detailed information about the management of students with special needs in inclusive schools State Junior High School 30 Surabaya and SAIM Junior High School (Sekolah Alam Insan Mulia) Surabaya.

The subjects in this study were the Principal, Deputy Principal for Student Affairs, Coordinator for Inclusion, Teachers and Homeroom Teachers, counseling teachers, as well as some students from each school. This research was conducted in the 2019-2020 school year. Data collection techniques using observation, interviews, and documentation. The data analysis technique used in this study was an interactive analysis model consisting of three components, namely data condensation, data triangulation, data presentation and make a conclusion. According to Ulfatin (2015) the stages of qualitative research with the case study method are as follows: (1) selecting research topics, (2) determining problems and topics, (3) designing designs, (4) collecting data, (5) analyzing data, (6) ) generalize data, (7) validate data, (8) write research reports.

\section{Results And Discussions}

\subsection{Management of Student with Special Needsin Inclusive School at State Junior High School 30 Surabaya and Alam Insan Mulia (SAIM) Junior High School Surabaya}

In inclusive education institutions, student management plays an important role in managing learning activities in schools. In accordance with this, according to the Special Guidelines for Providers of Inclusive Education at the Ministry of National Education, Directorate General of MANDIKDASMEN, Directorate of Special School Development (2007), student management aims to regulate various student activities so that learning activities at school can run smoothly, orderly and regularly and achieve the desired goal. According to Suhardan, et al. (2009: 206), the management function of students is a place for students to optimally develop their potential, both in terms of individuality, social, aspirations, needs and potential aspects of other students. Meanwhile, according to Suwardi and Daryanto (2017: 110) student management activities include student planning, student coaching, student evaluation and student mutation.

Planning for students at State Junior High School 30 Surabayaand SAIM Junior High School Surabaya includes (1) analysis of student needs, (2) student recruitment, (3) student selection, (4) student orientation, (5) placement students, and (6) recording and reporting of students. The planning of students at State Junior High School 30 Surabayaand SAIM Surabaya Junior High School has several similarities and differences. In planning the students of both schools make a Lesson Plan (RPP) first.

According to Hamid (2009: 35) Lesson Plan (RPP) is an actual, factual, conceptual, and contextual lesson plan that will actually be implemented in classrooms, laboratories, workshops, fields, markets, mosques, or in a school environment. So the Lesson Plan (RPP) is really a learning plan formed by the teacher and implemented by the teacher in learning activities which incidentally has an evaluation process. RPP is a teacher activity plan in the form of a step-by-step learning scenario regarding activities that will be carried out by students with the teacher related to the material that students will learn to achieve predetermined basic competencies (Suwarna, 2011: 67). Therefore, RPP in a plan is needed so that student activities become more structured in achieving learning objectives.

Furthermore, the recruitment process of the two schools carried out a different recruitment from students in general and the selection of Students with Special Needs (which would later be referred to as PDBK) at State Junior High School 30 Surabayawas carried out by collecting the results of psychological tests and assessment results while in Junior High School SAIM Surabaya was carried out through direct observation.In the journal Dian and Erawati (2017: 203) states that the recruitment of inclusive students is certainly different from normal students, for the recruitment of inclusive students is to identify children with disabilities, the essence of identification is interpreted as a process of screening children who experience disorders/deviations (physical, intellectual, social, emotional/behavior) in order to provide appropriate services.

In implementing the Students with Special Needs orientation, the two schools do the same thing as regular students. This is in accordance with the opinion of Sukarti Nasihin and Sururi. The orientation of inclusive students is adjusted to their ability to attend the orientation period, especially when it comes to physical training, this is in accordance with the principles of implementing inclusive education, namely the principle of individual needs, each child has different abilities and needs different, therefore education must be endeavored to adapt to the condition of the child (Dian and Erawati, 2017: 203). 
Furthermore, the placement of students with special needs at State Junior High School 30 Surabayawas carried out with restrictions in each class, namely for each class a maximum of 2 inclusive students and SAIM Junior High School Surabaya giving a quota of 2-3 students with special needs in one class. This is in line with Permendiknas number 70 article 5 paragraph 2 which states that the placement of inclusive students (class division) is allocated one seat in one study group, the placement of students in the class is also based on the previously obtained test scores.In terms of recording and reporting students with special needs State Junior High School 30 Surabayaand SAIM Junior High School Surabaya do the same thing with journaling and report cards at the end of each semester to find out the progress of students. In accordance with the opinion of Sukarti Nasihin and Sururi, the recording and reporting of students is very useful to find out the complete data of students starting from the time they are accepted in school until they graduate or leave school.

Management of student activities after planning, is coaching students. Bustari and Rahmawati (2005: 28) suggest that student coaching is carried out so that students know the environment in which they learn and adjust to school demands. In this study, coaching of students includes special services that support student management, including guidance and counseling services, library services, canteen services, health services and extracurricular activities.Lestariningrum (2017:10) the learning process does not require all students with special needs to be in regular classes at all times with all aspects of development to achieve the competencies that will be achieved. However, occasionally students with special needs can be in a special class or therapy room with a degree of disability accompanied by special teaching staff other than class teachers in regular classes.

In coaching students with special needs State Junior High School 30 Surabayaand SAIM Junior High School Surabaya have something in common, namely providing counseling services, libraries, canteens, health and extracurricular activities for students with special needs according to the needs of children with special needs. For Guidance and Counseling (BK) services, both schools provide counseling services with psychologists. At State Junior High School 30 Surabaya library services are very beneficial for students with special needs to increase their interest in reading culture of students and the SAIM Junior High School Surabaya library provides benefits to increase their ability to understand good reading.

Furthermore, canteen services in the two schools, State Junior High School 30 Surabayaand SAIM Junior High School Surabaya, have something in common with providing a canteen for students with special needs as well as regular students. Meanwhile, the two schools provide health services according to the needs of students with special needs and are carried out the same as regular students. As for extracurricular activities for students with special needs at State Junior High School 30 Surabaya, namely traditional sports and SAIM Surabaya Junior High School, they are offered the same as regular students, but are accompanied by a teacher in choosing them.

So there is no difference in coaching students in serving the needs of normal and inclusive students, this is in accordance with the Minister of National Education Regulation Number 70 of 2009 article 2 part (b) which states that realizing education that respects diversity, and is not discriminatory for all participants students. Based on the Regulation of the Minister of National Education Number 70 of 2009 article 2 part (b) above, school guidance and services to inclusive students must respect diversity and not be discriminatory, if the forms of guidance and services are different, of course there will be discrimination in providing services and this is against the principle -principles of implementing inclusive education (Dian and Erawati, 2017: 203).According to Wanjiru (2018:11) acceptance was further enhanced through recognition and nurturing of pupils' individual capabilities, including in non-examinable subjects. A majority of pupils felt that recognition by teachers and peers enriched their participation in school, expanding their learning experiences across the school community in distinctive ways.

Organizing students in inclusive schools is the same as students in general, namely by evaluating to measure the progress and success of students in the learning process. Evaluation of student learning outcomes is an activity to assess the process and learning outcomes of students in the form of curricular, cocurricular, and extracurricular activities which aim to see the learning progress of students in mastering the subject matter that has been studied by students in accordance with the goals that have been formulated ( Amirin, et al, 2010: 55).

The evaluation of planning and coaching students with special needs at State Junior High School 30 Surabayaand SAIM Junior High School Surabaya has a difference, for State Junior High School 30 Surabayathe evaluation is carried out every 3 months and for SAIM Junior High School Surabaya it is carried out at the end of the semester in the form of a planning matrix evaluation. As for the diagnostic test on inclusion students, State Junior High School 30 Surabayawas carried out on a diagnostic test on students with special needs and SAIM Junior High School Surabaya was not carried out on a diagnostic test on students with special needs. In the journal Dian and Erawati (2017: 203) states that the evaluation for inclusive students is the same as for other normal students. This is in accordance with the existing General 
Guidelines for the Implementation of Inclusive Education (2007): Assessment in an inclusive setting refers to the curriculum development model used, namely: if using the full regular curriculum model, the assessment will use the assessment system applicable to regular schools.

Based on this description, the management of students with special needs in inclusive schools at State Junior High School 30 Surabayaand SAIM Junior High School Surabaya includes (a) planning, analyzing the needs of students through observation and making Lesson Plans (RPP), the recruitment process is different from that of students. In general, the implementation of the orientation of students with special needs is carried out the same as regular, and the recording and reporting of students with special needs is done by making journals and report cards; (b) training for students of State Junior High School 30 Surabayaand SAIM Junior High School Surabaya has provided counseling services, libraries, canteens, health and extracurricular activities for students with special needs as well as regular and according to the needs of children with special needs; (c) The students' evaluation of State Junior High School 30 Surabayaand SAIM Junior High School Surabaya on planning and coaching students with special needs is carried out every 3 months and at the end of the semester; (d) The mutation of students of State Junior High School 30 Surabayaand SAIM Junior High School Surabaya can be seen that there is no mutation of students with special needs.

3.2 Inhibiting Factors in the Implementation of Management of Students with Spesial Needs in Inclusive Schools of State Junior High School 30 Surabaya and Alam Insan Mulia (SAIM) Junior High School Surabaya

According to Pratiwi (2015) there are challenges that need to be faced from implementing a fully inclusive school. These challenges come from within and from outside the school. Haryanto's research (at Wartono 2011) found that there are crucial problems related to the implementation of inclusive schools, including: (1) recruitment of special supervisors, so far the government has not appointed special supervisors who competently have the expertise to provide services to children with special needs. (2) the existence of infrastructure for children with special needs in inclusive schools is often a problem, so that the activities of organizing activities for children with special needs cannot run smoothly; (3) Minitoring and evaluation of inclusive schools is an integral part, not separately.

Inhibiting factors in the implementation of management of students with special needs in inclusive schools at State Junior High School 30 Surabaya and SAIM Junior High School Surabaya are as follows: 1. Student planning, including: (a) Parents who are less cooperative, (b) Students who are less cooperative ; 2. Development of Students, including: (a) Lack of support from parents of students with special needs, (b) The quality of teachers for students with special needs has not been maximized, (c) Students with special needs are less cooperative, 3. Student evaluations include: (a ) Lack of cooperation between teachers for students with special needs inclusion and subject teachers, and (b) less effective coaching. Teachers are known for having the ability to control their own class. The presence or presence of other teachers in the classroom is a new problem for some teachers. (Chandler, 2000).

In line with this, Dian and Erawati's research (2017: 203) shows that the factors that hinder the service management process for inclusive students at State Senior High School 4 Palangka Raya include internal factors, namely the teachers at State Senior High School 4 Palangka Raya have not all followed. upgrading or workshops on teaching procedures or providing services to inclusive students, and the absence of a special tutor for inclusive students, external factors, where parents entrust their children completely to the school and are no longer responsible for their educational development.

The result of research done by Sudomo(2012) showed that growth media from sand has given the best germination percentage compared to others growth germination media from soil, sawdust, and cocopeat. Growth media of sand possessed high germination percentage due to porosity and aeration that sprout needed to grow. Similar result was given in this research. The sand as germination media showed the most optimum result in all variables of parameters: germination percentage $(86.67 \%)$, maximum growth potential $(95.83 \%)$, index vigor $(38.33 \%)$, and germination velocity (3.967 \% etmal-1) (Table 2$)$.

\subsection{Solutions to Face Obstacles in the Implementation of Management of Student with Special Needs in Inclusive Schools of State Junior High School 30 Surabaya and Alam Insan Mulia (SAIM) Surabaya}

To overcome existing obstacles, parents should pay more attention and support the needs of each child in the field of education. In addition, educational institutions or schools also communicate more with parents of students with special needs in order to be more cooperative in providing information related to students with special needs. Not only that, schools or educational institutions to hold training to make inclusive teachers and subject teachers more qualified in learning activities. As suggested by Forlin (2007), partnership 
with parents is required to support inclusion in school. An effective whole-school approach must involve parents, who play a significant role in assisting teachers to meet the needs of the students by sharing important information and by helping students at home.

\section{Conclusion}

Based on the results of the research and the results of the discussion, it can be concluded that the management of students for children with special needs at State Junior High School 30 Surabaya and SAIM Junior High School Surabaya has been running optimally according to procedures. However, there are some things that must be considered and revised. In the technical management of students, it is necessary to pay attention again in the context of cooperation between teachers, parents and students with special needs. In terms of evaluation in student management, State Junior High School 30 Surabaya and SAIM Junior High School Surabaya must be able to learn and self-evaluation related to missing components and must be done in a timely manner. Then in the context of mutation, State Junior High School 30 Surabaya and SAIM Junior High School Surabaya must take appropriate action in the future because in both schools mutation has not been realized for students with special needs. The success of the management of children with special needs can be seen from the development of children with special needs and the better quality of existing learning, both from a technical point of view and in terms of human resources, it is the teacher who handles it

\section{References}

Allen, K. E \& Schwartz , I. S. (2001). The exceptional child: Inclusion in early childhood education (4th ed). New York: Thomson Learning Inc.

Ali Imron. (2011). Manajemen peserta didik berbasis sekolah. Jakarta: Bumi Aksara.

Amirin, M. Tatang at al. (2010). Manajemen pendidikan: Yogyakarta. UNY Pres.

Arikunto, S. (2002). Metodologi penelitian suatu pendekatan proposal. Jakarta: PT.Rineka Cipta.

Arikunto. (2010). Prosedur penelitian: suatu pendekatan praktek. Jakarta: Rineka Cipta.

Bogdan, R. C., Biklen, S. K., (1992).Qualitative Research for Education: an Introduction to Theory and Methods. Boston: Allyn \& Bacon.

Bustari \& Rahmawati. (2005). Buku pegangan kuliah manajemen peserta didik. Yogyakarta: Fakultas Ilmu Pendidikan UNY.

Chandler, L. K. (2000). A training and consultation model to reduce resistance and increase educatorknowledge and skill in addressing challenging behaviours. Special Education Perspectives, 9(1), pp3- 13.

Creswell, J. . (2007). Qualitative inquiry \& research design: choosing among.five approaches, 2 nd ed. California : Sage Publication.

Dadang Suhardan, dkk (2009). Manajemen pendidikan. Bandung:Alfabeta.

Daryanto dan Suwardi. (2017). Manajemen peserta didik. Yogyakarta: GavaMedia.

Dean, Joan. (2002). Managing special needs in the primary school. London: Taylor \& Francis e-Library.

Dyson, Alan. (2000). Schools and Special Needs: Issues of Innovation and Inclusion. London: Paul Chapman Publishing.

Forlin, C.L. (2007). Inclusive educational practices: A way forward for Hong Kong. Chinese Education and Society, 40, 4: 63-75.

Ilahi, M Tadir. (2013). Pendidikan inklusif konsep dan aplikasi. Yogyakarta : Ar- Ruzz Media

Kirk, Samuel. et. al. (2009). Educating exceptional children. New York : Houghton Mifflin Harcourt PublishingCompany.

Kristiawan, dkk. (2017). Manajemen Pendidikan. Yogyakarta: Deepublish

Lestariningrum, Anik. (2017). Implementasi Pendidikan Inklusif untuk Anak Usia Dini di Kota Kediri. Jurnal Children Advisoy Research and Education. Vol (4) 2

Lexy, J. Moleong. (2009). Metode penelitian kualitatif. Bandung: Remaja Rosdakarya.

Miles, Matthew B; Huberman, A Michael. (2009). Analisis data kualitatif: buku sumber tentang metode-metode baru. Jakarta: UI Press

Mudjito, et al. (2017). Management of inclusive school curriculum in indonesia. Advances in social science, education and humanities research, volume 118, 9th International Conference for Science Educators and Teachers (ICSET)

Nurani, et. Al. (2009). Konsep dasar pendidikan anak usia dini. Jakarta: Indeks

Pedoman Umum Penyelenggaraan Pendidikan Inklusif Departemen Pendidikan Nasional Direktorat Jendral MANDIKDASMEN Direktorat Pembinaan Sekolah Luar Biasa Tahun 2007.

Peraturan Menteri Pendidikan Nasional No. 70 th. 2009 tentang Pendidikan Inklusif bagi Peserta Didik yang 
Memiliki Kelainan dan Memiliki Potensi Kecerdasan dan/atau Bakat Istimewa.

Pratiwi. (2015). Sekolah Inklusi untuk Anak Berkebutuhan Khusus: Tanggapan Terhadap Tantangan Kedepannya. Prosiding Seminar Nasional Pendidikan. UMS: ISBN: 978-979-3456-52-2

Smith, J. A., Osborn, M. (2009). Analisis Fenomenologi Interpretatif. Dalam J. A. Smith. (ed). Psikologi Kualitatif : Panduan Praktis Metode Riset. Yogyakarta: Pustaka Pelajar.

Sugiyono. (2007). Metode penelitian kuantitatif kualitatif dan $r \mathcal{E}$. Bandung: Alfabeta.

Sujarwanto, et al. (2017). The management of students with special needs in inclusive school. Advances in social science, education and humanities research, volume 173, 1st International Conference on Education Innovation (ICEI 2017)

Tarmansyah. (2007). Inklusif, pendidikan untuk semua. Jakarta: Departemen Pendidikan Nasional, Direktorat Jendral Pendidikan Tinggi, Direktorat Ketenagaan.

Tilaar, H.A.R dan Riant Nugroho. (2012). Kebijakan pendidikan: pengantar untuk memahami kebijakan pendidikan dan kebijakan pendidikan sebagai kebijakan publik. Yogyakarta: Pustaka Pelajar

Ulfatin, Nurul. (2015). Metode penelitian kualitatif di bidang pendidikan: teori dan aplikasinya- studi kasus, etnografi, interaksi simbolik dan penelitian tindakan pada konteks manajemen pendidikan. Malang: Media Nusa Creative.

Undang-Undang Nomor 20 tahun 2003 tentang Pendidikan Nasional

Usman dan Murniati. (2019). Pengantar manajemen pendidikan. Banten: animage widiastuti, et al. 2016. The Evaluation of Inclusive Education Implementation forSpecial Need Children in Central Java Province. Innovation in Regional Public Service for Sustainability (ICPM 2016)

Wanjiru, Jenestar. (2018). Inclusive education for internally displaced Children in Kenya: children perceptions of their learning and development needs in post-conflict schooling. International Journal of Child Care and Education Policy. Vol (12) 7

Wartono. (2016). Pelaksanaan Model Pendidikan Inklusif di Wilayah DI Yogyakarta. Jurnal Study Islam. Vol (1) 1

Widyawati, et. al. (2017). The Description of Teachers Stressor and Manifestation of Special Needs Teachers in Inclusive and Special Schools in Jakarta. Internaional Journal of Indonesian Education and Teaching. Vol $(1), 1$

Yusuf, Muri. (2017). Metode penelitian kuantitatif, kualitatif, dan penelitian gabungan. Jakarta: Kencana 